\title{
Dietary practices of pregnant mothers from different ethnic groups in the Batticaloa district, Sri Lanka
}

\author{
S. Amuthenie ${ }^{1^{*}}$ and R. Sivakanesan ${ }^{2}$ \\ ${ }^{1}$ Department of Agricultural Chemistry, Faculty of Agriculture, Eastern University, Sri Lanka \\ ${ }^{2}$ Department of Biochemistry, Faculty of Medicine, University of Peradeniya, Peradeniya
}

\begin{abstract}
This study was aimed to investigate the dietary practices during pregnancy among mothers in the Batticaloa district. A cross-sectional study was conducted among 382 pregnant women at 12-24 weeks of pregnancy. Socio-economic and dietary data were collected by using pre tested food frequency questionnaire through face-to-face interview. Processed data were analyzed using Statistical Package for Social Sciences (SPSS) version 19. Of the pregnant mothers, $56 \%$ (214) were Tamils and $44 \%$ (168) were Muslims. Higher percentage of Tamil pregnant mothers reached their tertiary education level than Muslim mothers and Muslim pregnant mothers had higher income than Tamil pregnant mothers in the district. About 59\% of the Muslim pregnant women and only 28\% of Tamils were overweight before conception. On cereals intake 91.7\% Muslim pregnant mothers and $84.1 \%$ Tamil mothers received their energy from rice. Muslim pregnant women had high tendency to eat fruits especially orange (95.2\%), grapes (86.9\%) and watermelon $(54.2 \%)$, fish $(91.7 \%)$ and beef $(91.5 \%)$. Tamil women prefer to eat leafy vegetables $(88.2 \%)$ and bottle gourd $(58.9 \%)$. The ethnicity of the pregnant mothers highly influenced the consumption pattern of food group of meat, fruits and vegetables. Tamil pregnant mothers shows their preference to eat vegetable. And the frequency of consumption of meat is high among Muslim pregnant mothers.
\end{abstract}

Keywords: Dietary practices, Pregnancy, Nutritional status, Consumption pattern

\section{Introduction}

Maternal nutritional status during pregnancy has important implications for her health as well as the health of her children. It has been established that sufficient nutrition before and during pregnancy has the potential for the promotion of a long term health of the mother and her child (Khoushabi and Saraswathi, 2010). In the course of pregnancy, the quantity and quality of nourishment is of importance.
Dietary practices play a significant role in determining the long-term health status of both pregnant mother and growing fetus. Pattern of food consumption varies invariably among pregnant women residing in urban and rural areas in Sri Lanka. Due to different social welfare packages introduced by the successive governments after the independence, Sri Lanka has been able to achieve a high level of social development. Various development figures have proved it. 
From the health point of view even though Sri Lanka has achieved a good health status still a number of nutritional problems exist.

Unfortunately, due to the internal conflict over the last three decades in Sri Lanka especially in the Batticaloa region there is a lack of reliable data on nutritional status of pregnant women, especially on their food preferences and the dietary pattern during pregnancy. Hence, there is a need for an up-dated data on this important health problem in this region in order to provide proper nourishment during pregnancy and minimize the probability of Low Birth Weight (LBW). Therefore, this study was aimed to study the differences in the dietary practices among pregnant mothers from various ethnic groups residing in the Batticaloa district.

\section{Methodology \\ Study area, study design, and sampling method}

The study was carried out during April 2014 to March 2015 on a population based cross sectional study. Seven divisional secretariat divisions namely Manmunai North, Kattankudy, Manmunai South West, Manmunai West, Eravur Town, Oddamavady and Koralapattu North in the Batticaloa District were selected for this study. Tamil were predominant in areas such as Manmunai South West, Manmunai West and Koralaipattu North. Likewise, Kattankudy, Eravur town and Oddamavady are predominately occupied by Muslim and the Manmunai North divisional secretariat has Tamils and Muslims populations. The study population consisted of pregnant women attending the Ministry of Health $(\mathrm{MOH})$ antenatal clinics in the selected seven Divisional Secretariat areas from 14 DS Division in the Batticaloa district and this survey covered a representative sample size of 382 at $95 \%$ confidence level.
The study was approved by the Ethical Committee of the Faculty of Health Care Science, Eastern University of Sri Lanka.

A face-to-face interview with each participating mother was conducted personally in the local language (Tamil) with duration of 20 to 30 minutes. Pre tested questionnaire was used to collect data such as socio economic, age and ethnicity. Data on frequency of consumption of food items were estimated, using the food frequency questionnaire containing the list of food items and the frequency of consumption. Weight of pregnant women was measured by using solar digital weighing balance (SECA, Germany) and the self-reported pre pregnancy weight was recorded. The weight was taken without shoes and with as few clothes as possible. Height was measured in centimeters using a stadio meter. Processed data was analyzed using Statistical Package for Social Sciences (SPSS) version 19. Descriptive statistics were used to get the percentages and frequencies of variables used in this study.

\section{Results and Discussion}

\section{Distribution of pregnant mothers according to ethnicity in the DS divisions}

Table1 shows the distribution of the pregnant mothers based on their ethnicity in the DS divisions studied. In terms of ethnicity, 56\% (214) of Tamils and 44\% (168) of Muslim mothers participated in this study.

Pregnant mothers living in Manmunai west, Paddipalai and Vaharai DS divisions are predominantly Tamils, mothers living in Kattankudy and Eravur are fully muslims and $78.6 \%$ Tamils mothers and 21.4\% Muslim mothers are living in the Manmunai North Division (table 1). 
Table 1. Distribution of pregnant mothers according to ethnicity in the

\begin{tabular}{lll}
\hline DS division & Ethnicity & \\
\cline { 2 - 3 } Mamil & Muslim \\
\hline Manmunai North & $78.6 \%(33)$ & $21.4 \%(9)$ \\
Manmunai West & $100.0 \%(43)$ & 0 \\
Kaththankudy & 0 & $100.0 \%(57)$ \\
Paddipalai & $100.0 \%(88)$ & $0 \%$ \\
Eravur & 0 & $100 \%(47)$ \\
Vaharai & $100.0 \%(50)$ & 0 \\
Oddamavadi & 0 & $100.0 \%(55)$
\end{tabular}

Values are in \%. Number of women in parentheses

\section{Educational level of pregnant mothers}

The Chi square analysis showed a significant difference $\left(\mathrm{x}^{2}=13.064, \mathrm{P}<0.05\right)$ in the level of education between the ethnic groups. Among the pregnant mothers who have completed the primary education, $73.7 \%$ were Tamils and $26.3 \%$ were Muslims.

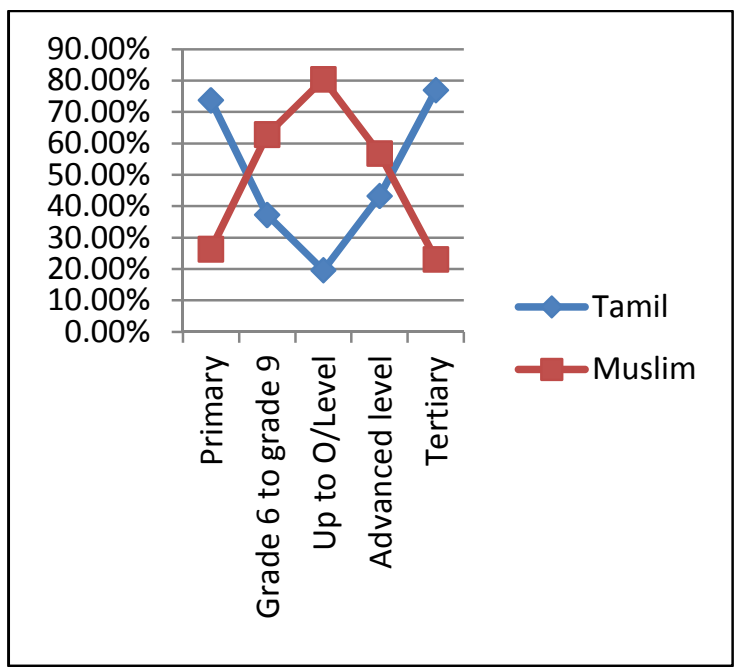

Fig. 1: Educational status of pregnant mothers according to ethnicity
A higher and significant percentage of Tamils $(76.9 \%)$ reached tertiary level of education than Muslims (23.1\%). The low educational level among Muslims in this district may be due to their social and cultural barriers forcing them to marry at an early age. Due to this early marriage they dropped out from their school life. Girl literacy until recent times has not been given much importance in Muslim community in the district. The participants' educational level was low in the study area and low educational attainment is one of the potential risk factors associated with poor nutritional status in pregnancy, most of the pregnant mothers reported that they dropped out of the schools and married during their younger age (teenage) due to their poor economic status. Therefore, educating mothers and giving them a good nutrition advice may help to improve their diet diversity and economic status as well.

\section{Family income}

Table 2 shows the percentage distribution of Tamil and Muslim pregnant mothers for different income level. Among Tamil mothers, around 39\% were with income level below Rs 5,000 per month whereas only $7.7 \%$ of the Muslim mothers were in this category. The family income of Muslim mothers was significantly higher than Tamil mothers $\left(x^{2}=4.207, \mathrm{p}<0.05\right)$. Income directly affects the economic status of a person and previous studies have shown that low income is associated with food insecurity (Ivers and Cullen, 2011). More than half $(63.6 \%)$ of the mothers completed up to secondary education (ordinary level). Because of this low educational level, it was very difficult 
to find a good job with adequate salary and therefore, they depend on their partners for finance to buy nutritious food item.

Table 2. Family Income

\begin{tabular}{rrc}
\hline Family income & \multicolumn{2}{c}{ Ethnicity (\%) } \\
\cline { 2 - 3 } range & & Muslim \\
\hline $5000 \&$ below & 38.8 & 7.7 \\
$5001-15000$ & 36.9 & 42.3 \\
$15001-25000$ & 16.8 & 32.1 \\
$25001-35000$ & 3.3 & 14.3 \\
$35001-50000$ & 2.8 & 1.8 \\
$50001 \&$ above & 1.4 & 1.8
\end{tabular}

$$
\mathrm{x}^{2}=4.207, \mathrm{p}<0.05
$$

\section{Pre pregnancy BMI of mothers according to ethnicity}

Ministry of Health (2012) Sri Lanka conducted survey on National Nutrition and Micro Nutrient in Sri Lanka supported by UNICEF estimated that, prevalence of pre pregnancy underweight, overweight and

Table 3. Pre pregnancy BMI of mothers obesity were $14.9 \%, 24.6 \%$ and $6.9 \%$ respectively. Present study results show, among the Tamils, 10.4\% were obese during their pre pregnancy period, $45.3 \%$ had normal pre pregnancy BMI, around 18\% were overweight and $26.4 \%$ were under weight.

\begin{tabular}{llllll}
\hline \multirow{2}{*}{} & \multicolumn{4}{l}{ Pre pregnancy BMI $\left(\mathrm{kgm}^{-2}\right)$} \\
\cline { 3 - 6 } & & $\begin{array}{l}\text { under } \\
\text { weight } \\
(<18.5)\end{array}$ & $\begin{array}{l}\text { Normal }(18.5- \\
\text { Tamil }\end{array}$ & $\begin{array}{l}\text { over weight } \\
(23-27)\end{array}$ & $\begin{array}{l}\text { Obese } \\
(>27)\end{array}$ \\
& Frequency & 56 & 96 & 38 & 22 \\
\multirow{3}{*}{ Muslim } & Percentage & $26.4 \%$ & $45.3 \%$ & $17.9 \%$ & $10.4 \%$ \\
& Frequency & 12 & 55 & 40 & 58 \\
& Percentage & $7.3 \%$ & $33.3 \%$ & $24.2 \%$ & $35.2 \%$ \\
\hline
\end{tabular}

$$
X^{2}=50.84, p<0.0001
$$

According to the findings, higher the percentage of Tamil pregnant mothers shows underweight compared to national level and it may increase the chances to low birth weight babies. Likewise, among Muslims only around $7 \%$ of the mothers were under weight, $33.3 \%$ were in the normal range, $24.2 \%$ were overweight and $35.2 \%$ were obese (Table 3). These concluded that, more than one third of Muslim mothers were obese during their pre pregnancy period and it was very higher $(35.2 \%)$ than the national level $(6.9 \%)$ of the country. 


\section{Consumption pattern of cereals, grains and their products}

Significant difference was observed between ethnic groups in bread consumption $\left(x^{2}=32.02\right.$, $\left.p<0.05\right) ; 26.2 \%$ of Muslims never consumed bread and $31.5 \%$ consumed bread once a week (Table 5). Regarding consumption of noodles, $28.5 \%$ of the Tamil mothers consumed noodles occasionally and $25.2 \%$ of them consumed noodles weekly whereas, nearly $88 \%$ Muslim mothers used to eat noodles. Among them, $23.8 \%$ were consuming occasionally, $35.7 \%$ consuming once a week and $22 \%$ consuming 2-4 times in a week. Many mothers stated that the higher price of the noodles (Rs.50/packet) in the market compared to rice (Rs. $80 / \mathrm{kg}$ ) was the reason for low consumption and higher percentage of Tamils were not choosing noodles as they were economically poorer than Muslims (Table 2). Around $40 \%$ of the Tamil mothers never consumed green gram, $22.9 \%$ and $21.5 \%$ consumed occasionally and once in a week respectively, whereas among Muslim mothers around 38\% consumed once a week and $19.6 \%$ consumed occasionally. The difference in consumption of green gram was due to the availability of the green gram in the areas. Most of the Tamil mothers live in the rural areas where cereals are not readily obtainable whereas, almost all the Muslim mothers live in the urban areas and they have the accessibility to buy those foods easily.Most of the Muslim mothers $(83.9 \%)$ and $62.6 \%$ of Tamil mothers did not consume brown rice during their gestation. Unpalatability was the reason for the low consumption of brown rice. There were no significant differences in corn flakes, pittu, string hoppers, hoppers, Rotty, chick pea and white rice consumption between Tamil and Muslim mothers. Parrott et al (2009) reported that pregnant women who ate cereals at least three times per week around the time of conception had significantly higher intakes of key micronutrients compared with women who did not eat cereal regularly. They further suggest that regularly consuming cereal in the pregnancy period may help reduce the prevalence of deficiencies in essential micronutrients, including folate and iron. In the present study, higher intake of cereals by pregnant mothers was observed (table 4) which will also have the benefit of absorbing micronutrients thus, preventing such micronutrient deficiencies.

The meat consumption pattern differed according to ethnicity. It could be observed (Table 5) that, $96.7 \%$ of the Tamils and $23 \%$ of the Muslim pregnant mothers never consumed beef roast, it was significantly lower in Tamils $\left(x^{2}=222.797\right.$, $\mathrm{p}=0.0001$ ) and $31.5 \%$ of Muslims ate beef roast once in a week.

Consumption pattern of beef curry showed significant difference between ethnic groups $\left(x^{2}=259.068, p=0.0001\right)$. Most of the Tamil pregnant mothers $(89.7 \%)$ and only $10 \%$ of the Muslim pregnant mothers $(10 \%)$ never consumed beef curry. More than half of the Muslim pregnant mothers (65.5\%) consumed beef curry once a week. Religious thoughts and beliefs are the reasons for not consuming beef by Tamils. The vegetarianism of the Hindus is based on two major beliefs- the sanctity of the cow, and the doctrine of "ahimsa" (not killing cattle) (Chloe Taylor, 2008). There is, however, no restriction on partaking of foods which do not involve the killing of the animal or products of the cow such as milk, curds and ghee which are regarded as sacred foods.

According to the table 5, higher $\%$ of Tamil participants consumed mutton than the Muslims. It was significantly higher in Tamils $\left(x^{2}=18.325, p=0.02\right)$ more than half of the Muslim mothers and only $38.8 \%$ of the Tamil mothers never ate mutton. The reason for the low consumption of mutton was its high price. 
Table 4. Consumption pattern of cereals, grains and their products

\begin{tabular}{|c|c|c|c|c|c|c|}
\hline Ethnicity & Never & Occasional & 1/week & $\begin{array}{l}2-4 \text { times } \\
\text { week }\end{array}$ & $\begin{array}{l}5-6 \\
\text { times/week }\end{array}$ & Daily \\
\hline \multicolumn{7}{|c|}{ Corn flakes } \\
\hline Tamil & $92.5(198)$ & $3.3(7)$ & $1.9(4)$ & $0.9(2)$ & $0.9(2)$ & $0.5(1)$ \\
\hline Muslim & $87.5(147)$ & $5.4(9)$ & $3.6(6)$ & $1.8(3)$ & $1.8(3)$ & 0 \\
\hline \multicolumn{7}{|c|}{ Noodles } \\
\hline Tamil & $26.6(57)$ & $28.5(61)$ & $25.2(54)$ & $16.4(35)$ & $1.9(4)$ & $1.4(3)$ \\
\hline Muslim & $11.9(20)$ & $23.8(40)$ & $35.7(60)$ & $22(37)$ & $5.4(9)$ & $1.2(2)$ \\
\hline \multicolumn{7}{|c|}{ Pittu } \\
\hline Tamil & $15.9(34)$ & $24.8(53)$ & $19.2(41)$ & $29(62)$ & $8.9(19)$ & $5(2.3)$ \\
\hline Muslim & $16.7(28)$ & $20.2(34)$ & $39.3(66)$ & $18.5(31)$ & $3.6(6)$ & $1.8(3)$ \\
\hline \multicolumn{7}{|c|}{ String Hoppers } \\
\hline Tamil & $11.7(25)$ & $21.5(46)$ & $24.3(52)$ & $24.8(53)$ & $15.4(33)$ & $2.3(5)$ \\
\hline Muslim & $10.1(17)$ & $15.5(26)$ & $28.6(48)$ & $23.2(39)$ & $11.3(19)$ & $11.3(19)$ \\
\hline \multicolumn{7}{|c|}{ Hoppers } \\
\hline Tamil & $44.9(95)$ & $21(45)$ & $18.2(39)$ & $10.7(23)$ & $3.7(8)$ & $1.9(4)$ \\
\hline Muslim & $38.1(64)$ & $20.2(34)$ & $28(47)$ & $9.5(16)$ & $3.6(6)$ & $6(1)$ \\
\hline \multicolumn{7}{|c|}{ Rotty } \\
\hline Tamil & $27.1(58)$ & $24.3(52)$ & $29(62)$ & $15(32)$ & $3.7(8)$ & $9(2)$ \\
\hline Muslim & $16.1(27)$ & $21.4(36)$ & $39.9(67)$ & $17.9(30)$ & $3(5)$ & $1.8(3)$ \\
\hline \multicolumn{7}{|c|}{ Green gram } \\
\hline Tamil & $39.3(84)$ & $22.9(49)$ & $21.5(46)$ & $11.7(25)$ & $2.3(5)$ & $2.3(5)$ \\
\hline Muslim & 23.2(39) & $19.6(33)$ & $38.1(64)$ & $15.5(26)$ & $1.8(3)$ & $1.8(3)$ \\
\hline \multicolumn{7}{|c|}{ Chickpeas } \\
\hline Tamil & $17.8(38)$ & $31.8(68)$ & $28.5(61)$ & $16.4(35)$ & $4.7(10)$ & $0.9(2)$ \\
\hline Muslim & $18.5(31)$ & $16.1(27)$ & $38.1(64)$ & $20.8(35)$ & $4.2(7)$ & $2.4(4)$ \\
\hline \multicolumn{7}{|c|}{ White rice } \\
\hline Tamil & $3.3(7)$ & $2.8(6)$ & $0.5(1)$ & $2.3(5)$ & $7(15)$ & $84.1(180)$ \\
\hline Muslim & $1.8(3)$ & $2.4(4)$ & $0.6(1)$ & 0 & $3.6(6)$ & $91.7(154)$ \\
\hline \multicolumn{7}{|c|}{ Brown rice } \\
\hline Tamil & $62.6(134)$ & $21.1(26)$ & $13.1(28)$ & $3.7(8)$ & $1.9(4)$ & $6.5(14)$ \\
\hline Muslim & $83.9(141)$ & $4.8(8)$ & $5.4(9)$ & $1.2(2)$ & 0 & $4.8(8)$ \\
\hline & & & Bread & & & \\
\hline Tamil & $14(30)$ & $20.6(44)$ & $19.2(41)$ & $30.8(66)$ & $9.8(21)$ & $5.6(12)$ \\
\hline Muslim & $26.2(44)$ & $20.2(34)$ & $31.5(53)$ & $11.9(20)$ & $4.8(8)$ & $5.4(9)$ \\
\hline \multicolumn{7}{|c|}{ Cream crackers } \\
\hline Tamil & $29.4(63)$ & $15.4(33)$ & $16.8(36)$ & $23.4(50)$ & $6.1(13)$ & $8.8(19)$ \\
\hline Muslim & $36.9(62)$ & $21.4(36)$ & $10.1(17)$ & $14.3(24)$ & $5.4(9)$ & $11.9(20)$ \\
\hline
\end{tabular}

Values are in \%. Number of women in parentheses 


\section{Meat consumption pattern according to different Ethnicity}

With respect to chicken consumption, around $46 \%$ of the Tamils consumed chicken curry occasionally and 34.1\% consumed once in a week. Among the pregnant mothers more than $90 \%$ of them consumed fish. Almost 1/3 of the mothers in both communities ate fish 2-4 times per week. This was different to the findings reported by Nyaruhucha (2009), and Dabrah et al (2012) who reported meat and fish as part of the commonly avoided foods by larger percent of the respondents in their studies. Chi square analysis revealed that the differences in the percentage of meat consumption such as beef roast $\left(x^{2}=222.797, p<0.001\right)$, beef curry $\left(x^{2}=259.068, p<0.0001\right)$, mutton and chicken $\left(x^{2}=56.228, p<0.0001\right)$ were significant among mothers between the two ethnic groups and the differences in the percent of fish, prawns and sausage consumption were non-significant

\section{Ethnicity and fruits consumption pattern}

According to the Chi square test, there was a significant difference in consumption patterns of apple $\left(x^{2}=38.302\right.$, $\mathrm{p}=0.001)$, orange $\left(\mathrm{x}^{2}=37.588, \mathrm{p}=0.0001\right)$, grapes $\left(x^{2}=46.861, \quad \mathrm{p}=0.001\right)$ and watermelon $\left(x^{2}=78.224, \quad p=0.0001\right)$ between ethnic groups.

Among Tamil pregnant mothers only $4.2 \%$ consumed apple daily whereas $17.2 \%$ of Muslim mothers consumed it daily. Likewise, $18.7 \%$ of Tamil pregnant mothers and $27.4 \%$ Muslim pregnant mothers respectively consumed apple once in a week.

There was a significant difference in orange consumption $\left(x^{2}=37.588\right.$, $\mathrm{p}=0.0001$ ), between ethnic groups. Almost all the Muslim pregnant mothers (95.2\%) consumed orange whereas among Tamils
$78 \%$ consumed orange during their gestational period. Significant difference in grapes consumption between ethnic groups was observed (Table 6). Among the pregnant mothers, $10.7 \%$ of Muslims andonly $2 \%$ of Tamils consumed grapes daily in the Batticaloa district. The reason may be the higher price of grapes in the market.

With respect to the consumption of water melon, significant difference was observed between ethnic groups. Among Tamils, 3.7\% consumed watermelon at least once in a week whereas $23.2 \%$ Muslim pregnant mothers consumed watermelon once in a week. Water melon is a seasonal fruit available during summer season. No significant differences were observed in the ethnic groups in fruits consumption such as, banana, guava, mango, pine apple, mangusteen, rambutan, pomegranate and avocado. From the table 6 , it is obvious that, banana is mostly consumed by the pregnant women on a daily basis. The study of Santiago et al (2013) on the consumption habits of pregnant women in California showed that banana is the third most commonly consumed fruit.

\section{Ethnicity and vegetable consumption pattern}

Significant differences were observed in consumption pattern of lettuce $\left(x^{2}=\right.$ 215.195, $p=0.0001)$, garlic $\left(x^{2}=39.295\right.$, $\mathrm{p}=0.002)$, tomato $\left(\mathrm{x}^{2}=36.069, \mathrm{p}=0.003\right)$, pumpkin $\left(\mathrm{x}^{2}=26.894, \mathrm{p}=0.0001\right)$, bottle gourd $\left(x^{2}=17.482, \quad p=0.002\right)$, manioc $\left(x^{2}=25.793, p=0.0001\right)$, and leafy vegetable $\left(x^{2}=28.782, \quad p=0.0001\right)$ between ethnic groups (Table 7).

More than half (52.4\%) of Muslim pregnant mothers consumed lettuce once in a week, whereas only $2.3 \%$ of Tamil mothers consumed lettuce once in a week in the Batticaloa district. 
Table 5. Meat consumption pattern by ethnicity

\begin{tabular}{|c|c|c|c|c|c|c|}
\hline Ethnicity & Never & Occasiona & 1/week & $\begin{array}{l}\text { 2-4 times/ } \\
\text { week }\end{array}$ & $\begin{array}{l}\text { 5-6 times/ } \\
\text { Week }\end{array}$ & Daily \\
\hline \multicolumn{7}{|c|}{ Beef curry } \\
\hline Tamils & 89.7 (192) & $6.5(14)$ & $3.7(8)$ & 0 & 0 & 0 \\
\hline Muslims & $9.5(16)$ & $11.3(19)$ & $65.5(110)$ & $13.7(23)$ & 0 & 0 \\
\hline \multicolumn{7}{|c|}{ Mutton } \\
\hline Tamils & $38.8(83)$ & $50(107)$ & $10.7(23)$ & $0.5(1)$ & 0 & 0 \\
\hline Muslims & $57.7(97)$ & $31(52)$ & $8.9(15)$ & $2.4(4)$ & 0 & 0 \\
\hline \multicolumn{7}{|c|}{ Chicken curry } \\
\hline Tamils & $11.7(25)$ & $46.3(99)$ & $34.1(73)$ & $7.9(17)$ & 0 & 0 \\
\hline Muslims & $9.5(16)$ & $12.5(21)$ & $62.5(105)$ & $14.9(25)$ & $1(0.6)$ & 0 \\
\hline \multicolumn{7}{|c|}{ Fried fish } \\
\hline Tamils & $13.6(29)$ & $15(32)$ & $16.8(36)$ & $32.2(69)$ & $20.1(43)$ & $5(2.4)$ \\
\hline Muslims & $14.9(25)$ & $14.3(24)$ & $24.4(41)$ & $33.9(57)$ & $8.3(14)$ & $4.2(7)$ \\
\hline \multicolumn{7}{|c|}{ Fish curry } \\
\hline Tamils & $9.8(21)$ & $12.6(27)$ & $10.3(22)$ & $35.5(76)$ & $26.6(57)$ & $11(5.1)$ \\
\hline Muslims & $8.3(14)$ & $8.9(15)$ & $15.5(26)$ & $38.7(65)$ & $19.6(33)$ & $9(15)$ \\
\hline \multicolumn{7}{|c|}{ canned fish } \\
\hline Tamils & $43.5(93)$ & $36.4(74)$ & $18.7(40)$ & $2.8(6)$ & - & $0.5(1)$ \\
\hline Muslims & $40.5(68)$ & $35.7(60)$ & $20.2(34)$ & $3.6(69)$ & 0 & 0 \\
\hline \multicolumn{7}{|c|}{ Prawns } \\
\hline Tamils & $34.1(73)$ & $33.2(7)$ & $22.4(48)$ & $7.9(17)$ & $1.4(3)$ & $0.9(2)$ \\
\hline Muslims & $49.4(83)$ & $22(37)$ & $22(37)$ & $6(10)$ & 0 & $0.6(1)$ \\
\hline \multicolumn{7}{|c|}{ Beef roast } \\
\hline Tamils & $96.7(207)$ & $2.3(5)$ & $0.9(2)$ & 0 & 0 & 0 \\
\hline Muslims & $23.2(39)$ & $25.6(43)$ & $31.5(53)$ & $14.9(25)$ & $2.4(4)$ & $2.4(4)$ \\
\hline \multicolumn{7}{|c|}{ Sausages } \\
\hline Tamils & $86(184)$ & $5.1(11)$ & $4.2(9)$ & $3.7(8)$ & 0 & $9(2)$ \\
\hline Muslims & $83.3(140)$ & $4.2(7)$ & $6(10)$ & $6(10)$ & $6(1)$ & 0 \\
\hline
\end{tabular}

Values are in \%. Number of women in parentheses 
Table 6. Consumption of fruits according to ethnicity

\begin{tabular}{|c|c|c|c|c|c|c|}
\hline Ethnicity & Never & Occasional & $\begin{array}{l}\text { Once/ } \\
\text { week }\end{array}$ & $\begin{array}{l}\text { 2-4 times/ } \\
\text { Week }\end{array}$ & $\begin{array}{l}\text { 5-6 times/ } \\
\text { Week }\end{array}$ & Daily \\
\hline \multicolumn{7}{|c|}{ Apple } \\
\hline Tamil & $19.6(12)$ & $34.6(74)$ & $18.7(40)$ & $17.3(37)$ & $5.6(12)$ & $4.2(9)$ \\
\hline Muslim & $10.7(18)$ & $22(37)$ & $27.4(46)$ & 10.1(17) & $11.9(20)$ & $17.9(30)$ \\
\hline \multicolumn{7}{|c|}{ Orange } \\
\hline Tamil & $22(47)$ & $34.1(73)$ & $22(47)$ & $13.1(28)$ & $3.3(7)$ & $5.7(12)$ \\
\hline Muslim & $4.8(8)$ & $26.8(45)$ & $33.9(57)$ & $14.3(24)$ & $5.4(9)$ & $14.9(25)$ \\
\hline \multicolumn{7}{|c|}{ Banana } \\
\hline Tamil & $6.5(14)$ & $10.3(22)$ & $17.8(38)$ & $27.1(58)$ & $14.5(31)$ & $23.9(51)$ \\
\hline Muslim & $4.8(8)$ & $11.3(19)$ & $19.6(33)$ & $11.9(20)$ & $11.9(20)$ & $40.5(68)$ \\
\hline \multicolumn{7}{|c|}{ Grapes } \\
\hline Tamil & $36.9(79)$ & $31.8(68)$ & $16.8(36)$ & $10.3(22)$ & $2.3(5)$ & $1.9(4)$ \\
\hline Muslim & $13.1(22)$ & $26.2(44)$ & $32.1(54)$ & $11.9(20)$ & $6(10)$ & $10.7(18)$ \\
\hline \multicolumn{7}{|c|}{ Guava } \\
\hline Tamil & $37.4(80)$ & $23.4(50)$ & $19.2(41)$ & $8.9(19)$ & $4.7(10)$ & $6.6(14)$ \\
\hline Muslim & $16.1(27)$ & $25.6(43)$ & $31.5(53)$ & $14.3(24)$ & $5.4(9)$ & $7.2(12)$ \\
\hline \multicolumn{7}{|c|}{ Mango } \\
\hline Tamil & $20.1(43)$ & $16.4(35)$ & $29(62)$ & $21(45)$ & $7.5(16)$ & $6.1(13)$ \\
\hline Muslim & $16.1(27)$ & $14.3(24)$ & 29.2(49) & $17.9(30)$ & $7.7(13)$ & $14.9(25)$ \\
\hline \multicolumn{7}{|c|}{ Pineapple } \\
\hline Tamil & $75.7(162)$ & $14(30)$ & 7.9(17) & $1.9(4)$ & $0.5(1)$ & 0 \\
\hline Muslim & $67.3(113)$ & $17.3(29)$ & $13.7(23)$ & $1.9(2)$ & $0.6(1)$ & 0 \\
\hline \multicolumn{7}{|c|}{ Mangusteen } \\
\hline Tamil & $84.6(181)$ & $9.8(21)$ & $5.1(11)$ & $.5(1)$ & 0 & 0 \\
\hline Muslim & $47.6(80)$ & $26.8(45)$ & $19.6(33)$ & $4.8(8)$ & $1.2(2)$ & 0 \\
\hline \multicolumn{7}{|c|}{ Rambutan } \\
\hline Tamil & $68.2(146)$ & $15.9(34)$ & $11.7(25)$ & $4.2(9)$ & 0 & 0 \\
\hline Muslim & $48.2(81)$ & $28.6(48)$ & $16.7(28)$ & $4.8(8)$ & $1.8(3)$ & 0 \\
\hline \multicolumn{7}{|c|}{ Pomegranate } \\
\hline Tamil & $62.1(133)$ & $20.1(43)$ & $14(30)$ & $3.3(7)$ & $0.5(1)$ & 0 \\
\hline Muslim & $34.5(58)$ & $36.3(61)$ & $23.8(40)$ & $3(5)$ & $1.8(3)$ & $6(1)$ \\
\hline \multicolumn{7}{|c|}{ Water melon } \\
\hline Tamil & $86.9(186)$ & $6.1(13)$ & $3.7(8)$ & $0.9(2)$ & $0.9(2)$ & $1.4(3)$ \\
\hline Muslim & $45.8(77)$ & $19.6(33)$ & $23.2(39)$ & $6(10)$ & $4.2(7)$ & $1.2(2)$ \\
\hline \multicolumn{7}{|c|}{ Avocado } \\
\hline Tamil & $94.4(202)$ & $4.2(9)$ & $0.45(1)$ & $0.9(2)$ & 0 & 0 \\
\hline Muslim & $90.5(152)$ & $4.8(8)$ & $4.2(7)$ & 0 & 0 & $1(0.6)$ \\
\hline
\end{tabular}

Values are in \%. Number of women in parentheses 
Table 7 (a). Ethnicity and vegetable consumption

\begin{tabular}{|c|c|c|c|c|c|c|}
\hline Ethnicity & Never & Occasional & $\begin{array}{l}\text { Once/ } \\
\text { Week }\end{array}$ & $\begin{array}{l}\text { 2-4 times/ } \\
\text { week }\end{array}$ & $\begin{array}{l}\text { 5-6 times/ } \\
\text { Week }\end{array}$ & Daily \\
\hline \multicolumn{7}{|c|}{ Carrot } \\
\hline Tamil & $8.4(18)$ & $21(45)$ & $34.1(73)$ & $24.3(52)$ & $6.1(13)$ & $6.1(13)$ \\
\hline Muslim & $4.8(8)$ & $20.2(34)$ & $39.3(66)$ & $20.2(34)$ & $5.4(9)$ & $10.1(17)$ \\
\hline \multicolumn{7}{|c|}{ Amaranthus } \\
\hline Tamil & $8.4(18)$ & $15.4(33)$ & $27.1(58)$ & $36.4(78)$ & $8.4(18)$ & $4.2(9)$ \\
\hline Muslim & $6(10)$ & $15.5(26)$ & $29.8(50)$ & $24.4(41)$ & $11.3(19)$ & $13.1(22)$ \\
\hline \multicolumn{7}{|c|}{ Leeks } \\
\hline Tamil & $24.3(52)$ & $17.8(38)$ & $34.1(73)$ & $19.6(42)$ & $3.3(7)$ & $0.9(2)$ \\
\hline Muslim & $20.2(34)$ & $17.9(30)$ & $45.2(76)$ & $11.9(20)$ & $2.4(4)$ & $2.4(4)$ \\
\hline \multicolumn{7}{|c|}{ Onion } \\
\hline Tamil & $10.3(22)$ & $9.8(21)$ & $4.7(10)$ & $5.1(11)$ & $4.7(10)$ & $65.5(140)$ \\
\hline Muslim & $8.9(15)$ & $7.7(13)$ & $10.1(17)$ & $4.2(7)$ & $8.9(15)$ & $60.1(101)$ \\
\hline \multicolumn{7}{|c|}{ Garlic } \\
\hline Tamil & $16.4(35)$ & $8.4(18)$ & $7(15)$ & $10.3(22)$ & $8.9(19)$ & $49.1(105)$ \\
\hline Muslim & $16.7(28)$ & $9.5(16)$ & $26.8(45)$ & $8.9(15)$ & $7.1(12)$ & $30.9(52)$ \\
\hline \multicolumn{7}{|c|}{ Lettuce } \\
\hline Tamil & 89.7(192) & $5.6(12)$ & $2.3(5)$ & $1.9(4)$ & $0.5(1)$ & 0 \\
\hline Muslim & $16.1(27)$ & $20.2(34)$ & $52.4(88)$ & $8.9(15)$ & $1.2(2)$ & $1.2(2)$ \\
\hline \multicolumn{7}{|c|}{ Tomato } \\
\hline Tamil & $27.1(58)$ & $16.4(35)$ & $25.7(55)$ & $21(45)$ & $4.7(10)$ & $5.2(11)$ \\
\hline Muslim & $8.3(14)$ & $14.9(25)$ & $26.2(44)$ & $22.6(38)$ & $10.7(18)$ & $17.3(29)$ \\
\hline \multicolumn{7}{|c|}{ Potato } \\
\hline Tamil & $7.9(17)$ & $11.2(24)$ & $22.9(49)$ & $41.6(89)$ & $10.7(23)$ & $5.6(12)$ \\
\hline Muslim & $4.8(8)$ & $11.9(20)$ & $38.7(65)$ & $24.4(41)$ & $8.9(15)$ & $11.3(19)$ \\
\hline \multicolumn{7}{|c|}{ Brinjal } \\
\hline Tamil & $43(92)$ & $15.4(33)$ & $22.9(49)$ & $16.4(35)$ & $1.4(3)$ & $0.9(2)$ \\
\hline Muslim & $25.6(43)$ & $25.6(43)$ & $38.1(64)$ & $8.9(15)$ & $1.2(2)$ & $0.6(2)$ \\
\hline \multicolumn{7}{|c|}{ Okra } \\
\hline Tamil & $15(32)$ & $19.2(41)$ & $35(75)$ & $25.7(55)$ & $3.7(8)$ & $1.4(3)$ \\
\hline Muslim & $11.3(19)$ & $23.8(40)$ & $53.6(90)$ & $10.7(18)$ & 0 & $1(0.6)$ \\
\hline \multicolumn{7}{|c|}{ Pumpkin } \\
\hline Tamil & $39.3(84)$ & $21(45)$ & $20.1(43)$ & $16.8(36)$ & $2.3(5)$ & $0.5(1)$ \\
\hline Muslim & $56.5(95)$ & $16.7(28)$ & $22.6(38)$ & $2.4(4)$ & $1.8(3)$ & 0 \\
\hline \multicolumn{7}{|c|}{ Bitter gourd } \\
\hline Tamil & 43(92) & $22.4(48)$ & $22(47)$ & $9.8(21)$ & $1.9(4)$ & $9(2)$ \\
\hline Muslim & $39.9(67)$ & $23.8(40)$ & $31(52)$ & $4.2(7)$ & $1.2(2)$ & 0 \\
\hline
\end{tabular}

Values are in \%. Number of women in parentheses 
Table 7 (b). Ethnicity and vegetable consumption

\begin{tabular}{|c|c|c|c|c|c|c|}
\hline Ethnicity & Never & Occasional & $\begin{array}{l}\text { Once/ } \\
\text { Week }\end{array}$ & $\begin{array}{l}\text { 2-4 times/ } \\
\text { Week }\end{array}$ & $\begin{array}{l}\text { 5-6 times/ } \\
\text { Week }\end{array}$ & Daily \\
\hline \multicolumn{7}{|c|}{ Snake gourd } \\
\hline Tamil & $49.5(106)$ & $21(45)$ & $20.6(44)$ & $7.9(17)$ & $0.5(1)$ & $0.5(1)$ \\
\hline Muslim & $37.5(63)$ & $23.8(40)$ & $32.7(55)$ & $4.2(7)$ & $1.8(3)$ & 0 \\
\hline \multicolumn{7}{|c|}{ Bottle gourd (calabash) } \\
\hline Tamil & $41.1(88)$ & $26.2(56)$ & $22(47)$ & $10.7(23)$ & 0 & 0 \\
\hline Muslim & $56(94)$ & $22.6(38)$ & $17.9(30)$ & $2.4(4)$ & $1.2(2)$ & 0 \\
\hline \multicolumn{7}{|c|}{ Lufa } \\
\hline Tamil & $40.2(86)$ & $22.4(48)$ & $23.8(51)$ & $12.6(27)$ & $09(2)$ & 0 \\
\hline Muslim & $29.8(50)$ & $20.8(35)$ & $37.5(63)$ & $10.1(17)$ & $0.6(1)$ & $1.2(2)$ \\
\hline \multicolumn{7}{|c|}{ Beet root } \\
\hline Tamil & $28.5(61)$ & $30.4(65)$ & $29.4(63)$ & $10.3(22)$ & $1.4(3)$ & 0 \\
\hline Muslim & $25.6(43)$ & $20.8(35)$ & $44.6(75)$ & $7.7(13)$ & $1.2(2)$ & 0 \\
\hline \multicolumn{7}{|c|}{ Drum stick } \\
\hline Tamil & $21.5(46)$ & $27.6(59)$ & $29.4(63)$ & $20.4(44)$ & $09(2)$ & 0 \\
\hline Muslim & $20.2(34)$ & $26.2(44)$ & $39.3(66)$ & $11.9(20)$ & $2.4(4)$ & 0 \\
\hline \multicolumn{7}{|c|}{ Capsicum } \\
\hline Tamil & $21(45)$ & $29.9(64)$ & $30.8(66)$ & $17.3(37)$ & $0.9(2)$ & 0 \\
\hline Muslim & $24.4(41)$ & $16.7(28)$ & $32.1(54)$ & $17.9(30)$ & $5.4(9)$ & $6(3.6)$ \\
\hline \multicolumn{7}{|c|}{ Sweet potato } \\
\hline Tamil & $40.2(86)$ & $34.6(74)$ & $20.1(43)$ & $4.7(10)$ & $0.5(1)$ & 0 \\
\hline Muslim & $54.2(91)$ & $25(42)$ & $16.1(27)$ & $2.4(4)$ & $1.8(3)$ & $.6(1)$ \\
\hline \multicolumn{7}{|c|}{ Manioc } \\
\hline Tamil & $13.6(29)$ & $18.2(39)$ & $28.5(614)$ & $30.4(65)$ & $8.4(18)$ & $0.9(2)$ \\
\hline Muslim & $28.1(47)$ & $20.4(34)$ & $33.5(56)$ & $13.8(23)$ & $3.6(6)$ & $0.6(1)$ \\
\hline \multicolumn{7}{|c|}{ Banana flower } \\
\hline Tamil & $28.5(61)$ & $30.8(66)$ & $27.6(59)$ & $11.7(25)$ & $0.9(2)$ & $0.5(1)$ \\
\hline Muslim & $26.2(44)$ & $35.1(59)$ & $32.7(55)$ & $5.4(9)$ & $0.6(1)$ & 0 \\
\hline \multicolumn{7}{|c|}{ Leafy vegetables } \\
\hline Tamil & $11.2(24)$ & $7.9(17)$ & $18.2(39)$ & $36.4(78)$ & $15(32)$ & $11.2(24)$ \\
\hline Muslim & $16.7(28)$ & $15.5(26)$ & $31.5(53)$ & $16.7(28)$ & $10.7(18)$ & $8.9(15)$ \\
\hline
\end{tabular}

Values are in \%. Number of women in parentheses

The reason for the low consumption of lettuce in the diet may be due to the lack of awareness on the importance of lettuce as preventing osteoporosis, irondeficiency anaemia, and believed to protect from cardiovascular diseases, agerelated muscular disease (ARMD), Alzheimer's disease and cancers (Department of Agriculture USA, 2009).
Significant difference in consumption of pumpkin $\left(x^{2}=26.894, p<0.05\right)$ was observed between two ethnic groups (Table 8a). Tamil pregnant mothers prefer to eat pumpkin than Muslim pregnant mothers. Among Tamils, $21 \%$ and $16.8 \%$ consumed pumpkin occasionally and 2-4 times per week respectively whereas among Muslims, $\quad 16.7 \%$ consumed 
pumpkin occasionally and only $2.4 \%$ consumed 2-4 times per week.

Significant difference was observed $\left(x^{2}=17.482\right.$, $\left.p<0.05\right)$ between ethnic groups in the consumption of bottle gourd (Lagenaria siceraria). Among Tamils 26.2\%, $22 \%$ and $10.7 \%$ of consumed bottle gourd occasionally, once in a week and 2-4 times per week respectively, whereas among Muslims 22.6\%, $17.9 \%$ and 2.4\% consumed bottle gourd occasionally, once in a week and 2-4 times per week respectively. In the rural areas most of the Tamil mothers grow bottle gourd wine in their boundary fence as it can be easily grown without proper agronomic practices and care. Sapana (2014) reported that Bottle gourd is one of the best vegetables for a mother. Because of its numerous benefits, it is advisable to include it regularly in the diet. It keeps hydrated during pregnancy, help in better milk production, and excellent for weight loss after exclusive breastfeeding. Present study found that considerable numbers of pregnant mothers are consuming bottle gourd.

Table $7 \mathrm{~b}$ also gives the details of manioc consumption. Among Tamil participants $18.2 \%$ consumed manioc occasionally, $28.5 \%$ consumed once in a week and $30.4 \%$ consumed 2-4 times in a week. Likewise, among Muslim 20.4\% of them consumed occasionally, 33.5\% consumed manioc once in a week and $13.8 \%$ consumed manioc 2-4 times in a week.

Consumption of leafy vegetable $\left(\mathrm{x}^{2}=\right.$ 28.782, p <0.05) was significantly high among Tamil mothers. Among Tamils $36.4 \%$ of mothers consumed leafy vegetables 2-4 times per week, 8\% occasionally consumed and $11.2 \%$ consumed daily. Among the Muslim community $31.5 \%$ of them consumed leafy vegetables once a week and only around 9\% consumed daily. Quezada et al., (2014) stated that green leafy vegetables contain many of the nutrients that women require during their pregnancy period. Furthermore, leafy greens are rich in antioxidants. They also contain constituents that improve the immune system and digestion. Due to their high fiber content, these vegetables may also help prevent constipation. Consuming green, leafy vegetables has also been linked with a reduced risk of low birth weight (Loy et al., 2011; Ramon et al., 2009). Therefore, proper awareness on the importance of having leafy vegetables in their diet should be created among the pregnant mothers in the study area.

\section{Conclusion}

Variation in the dietary pattern was observed between the Tamil and Muslim pregnant mothers in the Batticaloa district. It was observed that Tamil mothers were found to be in the low pre pregnancy BMI group than Muslim Mothers. The results of the study have shown that the ethnicity of the pregnant mothers highly influenced the consumption pattern of beef, mutton and chicken in the food group of meat. It shows the frequency of consumption of the above mentioned food is high among the Muslim pregnant mothers in the Batticaloa district. It was obvious that most of the pregnant women avoided the consumption of some fruits particularly avocado, pineapple, mangusteen and rambutan because of the lack of basic information on the nutritional importance of such fruits and those are seasonal fruits and available during the summer season in the market. Considering the ethnicity and the vegetables consumption among the pregnant mothers in the survey, Tamil pregnant mothers has shown their preferences to eat vegetables than Muslim pregnant mothers in the district. Therefore, awareness on the importance of diet diversity and nutrient intake during the pregnancy has to be created in the Batticaloa district to get healthier generation in future. 


\section{References}

Chloe Taylor, 2008. The precarious lives of animals: Butler, Coetzee and Animal ethics. Journal of Philosophy Today; Spring 52,1 .

Itandehui Castro-Quezada., Blanca Román-Viñas and Lluís Serra-Majem, 2014. The Mediterranean Diet and Nutritional Adequacy: A Review. Journal of Nutrients; 6: p 231-248.

Ivers L.C., and Cullen, K.A. 2011, Food insecurity: Special considerations for women. The American Journal of Clinical Nutrition.; Vol 94: p1740S-1744S.

Khoushabi, F., and Saraswathi, G. 2010. Impact of nutritional status on birth weight of neonates in Zahedan City, Iran. Journal of Nutrition Research and Practice, vol 4, p 339.

Koryo-Dabrah.A, Christina Nti.A and Adanu.R, 2012, “Dietary Practices and Nutrient Intakes of Pregnant Women in Accra, Ghana". Current Research Journal Biological Sciences, vol 4(4): p. 358-365.

Loy, S.L., Marhazlina, M., Azwany, Y.N.and Hamid Jan, J.M. 2011. Higher intake of fruits and vegetables in pregnancy is associated with birth size. Southeast Asian Journal of Tropical Medicine and Public Health; vol 42(5): p1214-1223.
Meredith Snook Parrott, Lisa M. Bodnar, Hyagriv N. Simhan, Gail Harger, Nina Markovic, and James M. Roberts, 2009 Maternal cereal consumption and adequacy of micronutrient intake in the periconceptional period. Journal of Public Health and Nutrition; vol 12(8): p 12761283.

Natioal Nutrient Database, 2009. Department of Agriculture, USA.

Nyaruhucha. C.N.M., 2009, "Food cravings, aversions and pica among pregnant women in Dar es Salaam, Tanzania". Tanzania Journal of Health Research, vol 11, pp. 1.

Ramón, R., Ballester, F., Iniguez, C., Rebagliato, M., Murcia, M. and Esplugues, A., 2009. Vegetable but not fruit intake during pregnancy is associated with newborn anthropometric measures. Journal of Nutrition, vol 139(3): p561-567.

Renuka Jayatissa, Gunathilaka, M.M., and Dulitha N. Fernando., 2012. National Nutrition and Micronutrient Survey report, Sri Lanka.

Sapana, 2014. Amazing Benefits of Bottle Gourd for New Moms. Go mama (News Letter) vol 24: 7. 